\title{
Social Insurance for Farmers in Poland and Lithuania - a Comparative Analysis
}

\author{
Astrida Miceikiene (iD) https://orcid.org/0000-0003-0708-8650 \\ Prof. dr., Vytautas Magnus University, Kaunas, Lithuania \\ e-mail: astrida.miceikiene@asu.It
}

\author{
Damian Walczak (iD) https://orcid.org/0000-0002-2986-9928 \\ Ph.D, Nicolaus Copernicus University in Torun, Torun, Poland \\ e-mail:dwalczak@umk.pl
}

\section{Sylwia Pieńkowska-Kamieniecka iD https://orcid.org/0000-0002-5818-2658 \\ Ph.D, University of Warmia nad Mazury, Olsztyn, Poland \\ e-mail: sylwia.pienkowska@uwm.edu.pl}

\begin{abstract}
The aim of the article is to present the social insurance of farmers in Poland and Lithuania. In the study, the following research methods were used: the descriptive method, a literature review, statistical analysis, and an economic analysis of the law. On the basis of the study results, it was concluded that both countries have a different model of social insurance for farmers. This results from political decisions, but also from other aspects which have an impact on agriculture in those countries. It needs to be stressed that in Poland this type of insurance is about $90 \%$ subsidized, whereas in Lithuania this system is self-sustaining.
\end{abstract}

Keywords: social security, pension, farmers, privileges

JEL: H55, H61, Q10 


\section{Introduction}

Each state is obliged to create a system of social security for its citizens. While making any decisions in this respect, every state is bound by top-down provisions of law. These regulations refer to minimum requirements which the law ought to comply with. One needs to mention, among others, the Directives of the International Labour Organization and the Regulations of the European Union (Hagemajer 2009, pp. 57-70; Cornelissen 2008, pp. 347-360). Regarding detailed regulations, particular countries seem to differ in various aspects. Due to specific conditioning, in some countries, certain social groups are offered different conditions of social protection for old age. In the European Union, one such group is farmers (Namiotko, Eirošius 2014, pp. 63-71; Kotsioni et al. 2007, pp. 317-319; Musiał 2014, pp. 349-361). A few member states of the EU which have separate systems of social insurance for farmers have established a separate institution, the European Network of Agricultural Social Protection Systems ${ }^{1}$, the aim of which is international cooperation in the sphere of social insurance for farmers.

The aim of the present article is to present the social insurance of farmers in two neighboring countries, Poland and Lithuania. In the study, the following research methods are used: the descriptive method, a literature review, statistical analysis and an economic analysis of the law.

Simultaneously, it needs to be highlighted that both countries are agriculturally diversified. According to Eurostat data (Agricultural Census 2010), in 2010 in Poland, there were 1.5 million farm households using over $14.4 \mathrm{mln}$ ha of farmland compared to 0.2 million farms using $2.7 \mathrm{mln}$ ha of farmland in Lithuania. About 1.8 million people worked in Polish agriculture, while in Lithuania only 0.15 million people (Eurostat 2012, 12-31). These numbers indicate that there are over ten times more workers and six times more farmland in Polish agriculture. However, farm households are larger in Lithuania (where the average acreage of a farm household is around 13 ha while in Poland it is around 9.7 ha). Taking into account the size of both countries, Poland with $312,679 \mathrm{~km}^{2}$ and Lithuania with $65,300 \mathrm{~km}^{2}$, as per the data of the World Bank, they are similar with respect to agriculture. In 2016, the share of agriculture in Gross Domestic Product (GDP) reached 2.7\% in Poland and 3.3\% in Lithuania (World Bank).

\section{Social insurance for farmers in Poland}

Farmers in Poland were covered by social security relatively late. The first act taking into account the security needs of this group was adopted in 1962, while the system of social security for individual farmers was established in 1977. The new law on the social insurance of farmers adopted in 1982 significantly broadened the scope of existing

1 http://www.enasp.eu/about/ (accessed: 1.04.2018). 
benefits, and the "new insurance system" moved insurance entitlements of individual farmers closer to the insurance system of employees (Jagła 2011, pp. 70-80; Walczak 2011, pp. 97-110). The current social insurance of farmers was regulated by the Act of 20 December 1990 (Act 1990), and implementation of tasks specified in the act was entrusted to an independent institution, i.e., the Agricultural Social Insurance Fund (KRUS). As part of social insurance for farmers, insured persons are subject to two types of insurance: accident, sickness, and maternity insurance as well as pension and disability insurance (Act 1990; Walczak 2011, pp. 98-135).

Moreover, to better understand the values presented, it should be pointed out that the social insurance of farmers (both types) can be obligatory and on request. People entitled to insurance include farmers, their spouses, and household members.

Pursuant to the law, accident, sickness and maternity insurance covers:

- each farmer whose farm household covers an area of agricultural land above one conversion hectare or a special branch of agricultural production,

- the household members of each farmer.

On request, accident, sickness and maternity insurance may cover:

- each farmer or household member if the agricultural activity constitutes a permanent source ${ }^{2}$ of income,

- any person who, while being a farmer, used their farmland for afforestation on terms set out in separate regulations.

Pension and disability insurance for farmers is obligatory for:

- each farmer (with their spouse) whose farm household covers an area of agricultural land above one conversion hectare or a special branch of agricultural production,

- each household member of such a farmer,

- people who are entitled to structural pension (and their spouse).

On request, pension and disability insurance may cover a person who:

— is subject to full accident, sickness and maternity insurance,

- was subject to insurance as a farmer and ceased to perform agricultural activity without acquiring the right to a pension or disability pension if they were subject to pension and disability insurance for at least a period of 50 quarters,

- receives agricultural disability pension as a periodic benefit.

Table 1 presents basic numbers which characterize this insurance. The number of insured people is decreasing dynamically. However, a big problem regarding social insurance of farmers in Poland concerns specific details. In 2010-2016, the number of insured farmers and their spouses decreased significantly. Yet, the number of household members (often covered by this type of insurance) did not change at all. The situation is similar in the case of those insured on request. While the number of people

2 Constant income from agricultural activity is required irrespective of the size and scope of the agricultural activity. Requiring a fixed, but even small income makes it possible to insure any person who declares any income. This is another element that makes it possible to insure an unlimited number of people in social insurance for farmers. 
subject to obligatory insurance decreased rapidly, the number of people insured on request (who often are not real farmers) decreased insignificantly.

Table 1. Number of people insured in social insurance for farmers in the years 2010 and 2016

\begin{tabular}{|l|c|c|}
\hline \multicolumn{1}{|c|}{ Specification } & $\mathbf{2 0 1 0}$ & $\mathbf{2 0 1 6}$ \\
\hline Farmers & $\mathbf{9 4 8 , 1 9 4}$ & $\mathbf{8 0 7 , 9 8 3}$ \\
\hline Spouses & 429,889 & 365,996 \\
\hline Household members & 157,378 & 155,712 \\
\hline Total & $1,535,461$ & $1,329,691^{*}$ \\
\hline Insured - obligatory & $1,365,967$ & $1,173,218$ \\
\hline Insured - on request & 169,494 & 161,980 \\
\hline Total & $1,535,461$ & $1,335,198^{*}$ \\
\hline
\end{tabular}

* Due to the available data, the number of people insured in both criteria is not the same. Source: (KRUS 2017, p. 26); (KRUS 2011, p. 24); (NIK 2017, p. 212).

Social insurance for farmers has changed since 1990. Initially, the number of beneficiaries was much higher than the number of insured people. This was mainly due to the political and economic transformation in the early 1990s and "the escape into disability allowance" which at that time was very easy to obtain. However, in the long perspective, the number of insured people, as well as beneficiaries, decreased notably, due to numerous social, demographic and economic changes. For public finances, it is important that the number of beneficiaries decreases faster than the number of those subject to insurance. This, as shown in Figure 1, results in an increasingly favorable financial situation of the social insurance system in Poland (Walczak 2017, pp. 23-33).

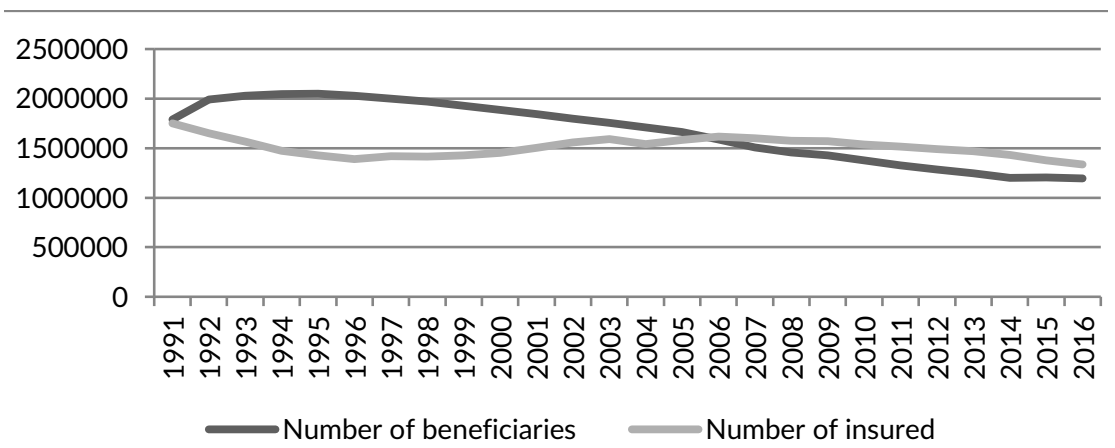

Figure 1. The number of beneficiaries and insured people in KRUS, and the relationship between them (in \%)

Source: own study based on KRUS, www.krus.gov.pl (accessed: 25.01.2018).

As presented in Table 2, the share of budget subsidy in the income of the pension and disability fund in the analyzed period decreased. This results mainly 
from the reduction in the number of beneficiaries. In addition, the share of this subsidy in the Gross Domestic Product in Poland decreased. In 2000 it was 1.8\%, and in 2015 it was $1.0 \%$ of GDP (Walczak 2017, p. 32). Despite the positive changes regarding the sum of the budget subsidy to the social insurance of farmers, it is still an important position in the state budget, and in the face of no planned changes regarding social insurance for farmers, it will evidently remain at the same level.

Table 2. Financial situation of the pension and disability fund

\begin{tabular}{|l|c|c|}
\hline \multicolumn{1}{|c|}{ Specification } & 2010 & 2016 \\
\hline $\begin{array}{l}\text { Subsidy from the state budget (Pension and Disability Fund) } \\
\text { (billion PLN) }\end{array}$ & 14.936 & 16.373 \\
\hline Revenue from pension and disability contributions (billion PLN) & N/A & 1.429 \\
\hline Share of subsidy in total revenue & $91.4 \%$ & $83.5 \%$ \\
\hline
\end{tabular}

Source: own study based on KRUS, www.krus.gov.pl (accessed: 25.01.2018).

All farmers (spouses and household members) pay the same social insurance contribution. In the case of pension and disability insurance, the monthly contribution is 179 PLN while the rate of accident, sickness and maternity insurance is 42 PLN per month. It can be differentiated in two cases:

1. The basic contribution for pension and disability insurance for farmers who also conduct non-agricultural business activity is doubled (in 2016 by 83,683 people).

2. The contribution for pension and disability insurance for farmers also depends on the size of the farm household (in 2015 it was barely 19,929 people).

Table 3. The amount of additional contribution for pension and disability insurance for farmers

\begin{tabular}{|l|c|c|}
\hline $\begin{array}{c}\text { The size of farm household } \\
\text { in conversion hectares }\end{array}$ & $\begin{array}{c}\text { Additional contribution } \\
\text { in relation to basic pension }\end{array}$ & $\begin{array}{c}\text { The amount of additional } \\
\text { contribution for pension and } \\
\text { disability insurance (in PLN) }\end{array}$ \\
\hline$<50$ ha & $0 \%$ & 0 \\
\hline acreage $50-100$ ha & $12 \%$ & 106 \\
\hline acreage 100-150 ha & $24 \%$ & 213 \\
\hline acreage 150-300 ha & $36 \%$ & 319 \\
\hline.$>300$ ha & $48 \%$ & 425 \\
\hline
\end{tabular}

Source: base on (Act 1990).

Moreover, the Agricultural Social Insurance Fund is responsible for paying contributions for the health insurance of those who are insured and their beneficiaries to the National Health Fund (NFZ). The contribution for retirees and pensioners is charged from their benefits, that is, de facto from the state budget. However, in the case of farmers, it is more complicated. Farmers with land below 6 ha do not pay this contribution, it is the State who pays it for them; meanwhile, farmers with farms bigger than 6 ha pay the contribution individually. 
Table 4. Contributions for health insurance paid to NFZ for 2015-2016

\begin{tabular}{|l|c|c|}
\hline \multicolumn{1}{|c|}{ Specification } & 2015 & 2016 \\
\cline { 2 - 3 } & $\begin{array}{c}\text { The amount } \\
\text { of contribution } \\
\text { (in thousand PLN) }\end{array}$ & $\begin{array}{c}\text { The amount } \\
\text { of contribution } \\
\text { (in thousand PLN) }\end{array}$ \\
\hline In total, including: & $3,284,136$ & $3,287,899$ \\
a) contribution from retirees and pensioners & $1,384,347$ & $1,388,123$ \\
b) contribution for farmers and household members* & $1,862,004$ & $1,862,004$ \\
c) special branches of agricultural production & 37,785 & 37,772 \\
\hline
\end{tabular}

* Around 1.7 billion PLN is paid by the State for farmers who own below 6 ha of farmland as compared to only 0.1 billion PLN paid individually by farmers.

Source: own study based on KRUS, www.krus.gov.pl (accessed: 25.01.2018).

As indicated, one may observe that the system of social insurance for farmers is, in many aspects, highly beneficial for farmers (mainly the amount of contribution). However, in the case of benefits, it definitely is not. The agricultural pension is, on average, half of the one received from the common system. Also, it should be added that agricultural pensions are very flattened. The authors do not have statistics in this respect, but it may be assumed that about $95 \%$ of agricultural pensions are in the range of $\pm 10 \%$ of the average pension. The data presented in the article also signal a significant issue regarding social security of farmers in Poland, namely the adequacy of agricultural benefits protecting farmers from poverty or income compensation in the life cycle (Chybalski, Marcinkiewicz 2017, pp. 99-117).

Table 5. Average pension in years 2014-2016 (in PLN)

\begin{tabular}{|l|c|c|c|c|}
\hline \multicolumn{1}{|c|}{ Type of system } & Paying institution & 2014 & 2015 & 2016 \\
\hline $\begin{array}{l}\text { Pension from SIF } \\
\text { (common system) }\end{array}$ & ZUS & $2,043.11$ & $2,096.55$ & $2,131.75$ \\
\hline Agricultural pension & KRUS & $1,176.46$ & $1,209.81$ & $1,210.30$ \\
\hline
\end{tabular}

Source: CSO 2015, pp. 24-28; CSO 2016, pp. 24-28; CSO 2017, pp. 30-31.

\section{Social insurance for farmers in Lithuania}

Pursuant to the legal acts of the Republic of Lithuania, a farmer is considered to be a natural person engaged in agricultural activities on his/her own or together with partners, with the farm being registered in the register of farmers' farms. The farmer becomes the taxpayer as soon as he/she registers the farm. Farmers pay personal income, land, value-added, and state social security taxes, as well as health insurance contributions. In certain cases, they are imposed with the duty to pay other taxes and contributions established under the legal acts of the Republic of Lithuania. Their personal property is inseparable from the farm assets. Farmers are entitled to engage in agricultural activities covering the production and treatment of agricultural products, 
the processing of the agricultural products produced and treated at the farm, the production of food products from the agricultural products produced and treated at the farm, and the sale and provision of agricultural services.

The evolution of the farmers' social security system following the restoration of independence of Lithuania could be viewed as consisting of three key stages, each characterized by features determined by the development of the country itself:

1. Between 1990 and 2008, agricultural entities were exempted from paying social security and health insurance contributions, and did not have any social guarantees.

2. Between 2009 and 2017, farmers paid state social security and health insurance contributions with a number of tax advantages, and, despite the latter, became insured under the health and pension, and maternity (paternity) insurance schemes.

3. Since 2018, the approach towards people engaged in agricultural activity has changed substantially, and they have become subject to the state social security and health insurance schemes, with few reservations, the same as other self-employed persons.

It should also be noted that the pension system reform was launched in Lithuania in 2003. Since 2004, farmers and other residents have been entitled to allocate a share of the state social insurance contribution to private pension funds for the accumulation of pensions. At present, farmers willing to accumulate pensions in private pension funds are required to pay additional contributions of $2 \%$.

Farmers' state social security and health insurance systems in Lithuania are distinctive in that the farmers are classified by certain criteria - the economic size of agricultural holdings (farms) (hereinafter - the ESU), and value-added tax payer's status - for taxation purposes.

Farmers' and their partners' social security and health insurance contribution base is comprised of their taxable income. This indicator is calculated as the difference between the farmer's or his partner's taxable income and costs related to earning the income governed by the legal acts. Farmers' and their partners' state social security and health insurance contributions are presented in Table 6.

Farmers and their partners are subject to mandatory state social security if the size of their agricultural holding is 4 or more ESU. By paying the state social security contributions, farmers become eligible for retirement or disability pension, and maternity, paternity, and parental leave benefits.

One of the major issues related to the farmers' and their partners' social security and health insurance system in Lithuania is the instability of the system. The system is subject to frequent changes, which makes it difficult for farmers to plan their activities and cash flows. In 2009, the size of social security contributions paid by farmers and farmers' partners was $8 \%$, in 2010 - 16\% of the chosen income equal to at least the minimum monthly wage and not exceeding the monthly insurable earnings approved by the Government for the current year. 
Table 6. Farmers' and partners' state social security and health insurance contributions

\begin{tabular}{|c|c|c|c|}
\hline Contributions & Taxation base & $\begin{array}{l}\text { Contribution } \\
\text { rate }\end{array}$ & Contribution advantages \\
\hline \multirow[t]{2}{*}{$\begin{array}{l}\text { State social } \\
\text { security } \\
\text { contributions }\end{array}$} & $\begin{array}{l}50 \% \text { of the farmer's taxa- } \\
\text { ble income, not exceed- } \\
\text { ing } 14 \text { average insurable } \\
\text { earnings of the country, } \\
\text { if the farmer or farmer's } \\
\text { partner is required to file } \\
\text { a tax return following the } \\
\text { end of the year }\end{array}$ & \multirow[t]{2}{*}{$28.9 \%$} & \multirow[t]{2}{*}{$\begin{array}{l}\text { Farmers whose ESU* is } 4 \text { or less are } \\
\text { not required to pay the contributions. } \\
\text { Farmers and farmers' partners are } \\
\text { not required to pay the contributions } \\
\text { if they are paid a retirement, social } \\
\text { as-sistance or disability pension. }\end{array}$} \\
\hline & $\begin{array}{l}12 \text { minimum monthly } \\
\text { wages annually, if the } \\
\text { farmer or farmer's part- } \\
\text { ner is not required to file } \\
\text { a tax return following the } \\
\text { end of the year }\end{array}$ & & \\
\hline \multirow{2}{*}{$\begin{array}{l}\text { Health } \\
\text { insurance } \\
\text { contributions }\end{array}$} & \multirow[t]{2}{*}{$\begin{array}{l}12 \text { minimum monthly } \\
\text { wages annually }\end{array}$} & $\begin{array}{l}3 \%, \text { if } \mathrm{ESU}^{*} \\
\text { is } 2 \text { or less }\end{array}$ & \multirow{2}{*}{$\begin{array}{l}\text { Farmers or farmers' partners, for whom } \\
\text { the health insurance contributions are } \\
\text { paid (e.g. under employment contracts, } \\
\text { civil service, public office, etc.) or the } \\
\text { farmer is insured from state budget } \\
\text { (e.g. on the basis of retirement, disabili- } \\
\text { ty, etc.) or is paid sickness, occupation- } \\
\text { al rehabilitation, maternity, paternity, } \\
\text { parental leave benefits, are not } \\
\text { required to pay the contributions. }\end{array}$} \\
\hline & & $\begin{array}{c}9 \% \text {, if ESU } \\
\text { is more } \\
\text { than } 2\end{array}$ & \\
\hline
\end{tabular}

* The ESU of the farm is calculated regarding the standard gross margin (SGM) of the types of products of the agricultural farm and the earnings from the provision of services to agriculture, if the holding or farm provides such services. The ESU is determined by dividing the SGM by the ESU equal to EUR 1,200. The SGM of the farm is determined by summing up the products of multiplying the SGM of the respective type of product of the holding or farm by the areas of grown crops and the average annual number of farm animals of each type, areas of aquaculture ponds and volumes of recirculating aquaculture systems, and adding the earnings from the provision of services to agriculture, which are recalculated into SGM by using the coefficient 0.5524 (European Commission 2010).

Source: own study.

Since 2011, farmers and farmers' partners whose agricultural holding size is greater than 4 ESU have been required to pay social security contributions of $28.5 \%$.

In 2011 and 2012, state social security contributions were calculated according to the $28.5 \%$ rate, but the size of the farmers' and their partners' contributions depended on whether the earnings generated by operations of the farm were subject to personal income tax or not. If the earnings were not subject to personal income tax during the tax period, the farmers paid minimum contributions. If farmers and farmers' partners paid personal income tax during the tax period, the amount of payable contributions depended on the taxable earnings from the farm activity. They paid contributions calculated on the basis of the minimum monthly wage on a monthly basis, and, following the end of the year, the size of contributions had to be recalculated according to the taxable earnings received, and the resulting difference had to be paid. 
Farmers and farmers' partners whose agricultural holding size was 14 ESU or smaller had the option to not pay the state social insurance contributions if they received a retirement pension.

In 2009, additional amendments were adopted to the Law of the Republic of Lithuania on Health Insurance governing farmers' health insurance contributions.

The sizes of mandatory health insurance contributions applicable to the farmers and their partners depended on the ESU of their agricultural holding. Those whose ESU was 2 or smaller, irrespective of their VAT payer status, paid the mandatory health insurance contributions equal to $3 \%$ of the minimum monthly wage on a monthly basis. If the farm size was more than 2 ESU and it did not have the VAT payer status, it was subject to $9 \%$ mandatory health insurance contributions. If the farmer's agricultural holding size was greater than 2 ESU but did not exceed 4 ESU, the farmer was subject to contributions of $9 \%$ of the minimum monthly wage, irrespective of his/her VAT payer status. Farmers whose agricultural holding size was 4 ESU or greater paid the contributions of $9 \%$ of the minimum monthly wage.

The farmers and their partners who received a retirement or disability pension, or who were insured under a different mandatory health insurance category of the insured, were exempt from paying the mandatory health insurance contributions.

Those whose farm size is greater than 4 ESU are insured under the pension, sickness, maternity, paternity, and parental insurance schemes.

Farmers and their partners are eligible for the retirement and disability pension if they have the minimum number of pensionable years in their background: for the retirement pension - 15 years, for the disability pension - the eligibility depends on the person's age, the start date of the disability and the date of retirement or recognition of the farmer as the disabled.

Since 2012, in Lithuania, the default retirement pension age has been increased each year, until it reaches the threshold of 65 years (for both women and men) in 2026. In 2018, the default retirement pension age for women is 62 years and 4 months, for men - 63 years and 8 months. The size of retirement and disability pension depends on the actual number of pensionable years in the background, the number of accounting units, the value of the accounting unit approved by the State Social Security Fund, and the sizes of the basic pension.

Sickness, maternity, and paternity benefits are awarded and paid to farmers and farmers' partners under the procedure that also applies to other people eligible for the benefits.

Sickness benefit is paid by the employer for the first two days of sickness. It is equal to $80-100 \%$ of the recipient's average wage. Starting with day 3 , the benefit comprised of $80 \%$ of the recipient's compensated wage is paid by the State Social Security Fund. This benefit is paid for working days only and cannot be lower or higher than the established limits. The established minimum and maximum daily sickness benefit applies. The sickness benefit paid from the fund budget cannot be lower than 15\% of the average national monthly wage effective during the quarter preceding the previous quar- 
ter before the month of the start of temporary incapacity to work. If the compensated wage for calculating the sickness benefit is lower, the benefit is calculated by applying the latter. The maximum compensated wage for calculating the sickness benefit cannot exceed two average national monthly wages effective during the quarter preceding the previous quarter before the month of the start of the incapacity to work.

Female farmers or female partners of farmers are eligible for the maternity benefit, which is equal to $100 \%$ of the recipient's compensated wage. The benefit is calculated according to the person's insurable earnings for 12 subsequent calendar months before the last calendar month prior to the starting month of eligibility for the maternity benefit. The minimum monthly maternity benefit cannot be lower than six basic social insurance benefits effective during the last quarter before the starting day of the eligibility for the benefit. The benefit is awarded for 126 calendar days and paid for the working days of the respective period on the basis of a five-day working week.

The parental benefit is awarded to a father or mother raising a child not older than two years. The benefit is $100 \%$ of the recipient's compensated wage. Male/female farmers or male/female partners of farmers are eligible for the benefit. One of the two following options of the benefit are available:

- the benefit is paid until the child turns one. In this case, the benefit is $100 \%$ of the compensated wage;

- the benefit is paid until the child turns two. In this case, during the first year, the benefit is $70 \%$, and during the second year $-40 \%$ of the compensated wage.

\section{Implications of the Farmers' Social Security and Health Insurance: A theoretical perspective and the case of Lithuania}

Analysis of the recent scientific literature, when farmers have been included in the common tax system in Lithuania (since 2009), has shown that only a few researchers (Grakauskas, Marcijonas 2005; Juškevičiené, Lakis 2010; Slavickiené, Savickienè 2012; Juškevičienè 2012; Miceikienė, Novošinskiené, Savickienè 2014) have analyzed farmers' social insurance and health insurance contributions and the related implications.

The farmers' social insurance and health insurance system has been little analyzed by researchers in an integrated way, and only a few research works of limited scope have been identified in the scientific literature (Slavickienè, Savickienè 2012; Miceikiené, Novošinskienè, Savickienè 2014). Foreign authors tend to take more interest in this subject. Several scientific approaches could be identified on the basis of the conducted analysis of the research publications:

- researchers who claim that farmers' taxation in the form of social security and health insurance contributions should be treated separately from the common national social insurance policy, as farmers should be provided with preferential 
taxation conditions due to the specific nature of their operations, and the preferences are referred to as the support to agriculture (Hill, Blandford 2007; Parlińska 2008; Slavickienè, Savickienė 2012; Slavickienė, Čiulevičienè, Savickienė 2012; Miceikiene, Besupariene 2016);

- researchers who claim that preferences related to the social security and health insurance contributions applicable to farmers are not in line with the principle of tax fairness, and that the farmers should be either exempt from payment of the contributions or be subject to the same contributions as everyone else (Zhong et al. 2011).

The most common issue raised by researchers is that the same regulations pertaining to the social security and health insurance contributions cannot apply to large and small farmers' farms, and taxes should be collected taking into consideration the specifics of the farm's operations and its importance to society.

Since farmers in Lithuania have started paying the state social security and mandatory health insurance contributions, the farms have been grouped by several criteria for the purpose of paying the contributions: the economic size of the agricultural holding controlled by them expressed in the economic size units (ESU) and their value-added taxpayer status.

The author has noted that it is specific to Lithuania that the VAT payer status is the basis for paying other taxes, including the state social security and health insurance contributions. This violates the horizontal taxation principle.

In Lithuania, researchers have emphasized that the main implication of farmers' state social insurance and health insurance contributions by 2018 was the application of regressive taxation, i.e., the higher the farm profit, the lower the burden of these contributions. Since 2018, the situation has been solved partially by raising the upper threshold of contributions. Nonetheless, signs of the regressive character of the taxes have remained.

In general, the following key issues could be identified following analysis of the farmers' social security and health insurance implications referred to by the researchers:

- Different taxation conditions are applied to farmers by grouping them into separate groups: different state social security and health insurance contribution rates and a different taxation base. The system weakly correlates disproportionately to revenues generated by the farms, and it considerably reduces the economic viability of small and medium-sized farms.

- The differentiation of farms by grouping them into separate groups by economic size of the farm and VAT payer status for taxation purposes makes the tax system complex, not fully in line with taxation principles, causes regression in the system, and increases the tax burden on small and medium-sized farms while reducing the burden on large farms.

- The relatively high burden of social security and health insurance contributions leads to a reduction of the economic viability of small and medium-sized farms. 
- Farmers' duty to pay the state social security and health insurance contributions separately on the basis of the revenues from the sale of their farm's non-current assets violates the principle of fairness and increases the tax burden artificially.

\section{A comparison of social insurance for farmers in Poland and in Lithuania}

As stated above, Poland, in contrast to Lithuania, has a separate system of social insurance for farmers. Table 7 presents the full scope of social insurance systems for farmers in Poland and Lithuania.

Table 7. Comparison of social insurance for farmers in Poland and Lithuania

\begin{tabular}{|c|c|c|}
\hline Specification & Poland & Lithuania \\
\hline $\begin{array}{l}\text { Are farmers in your country covered by the public } \\
\text { social insurance system together with other social } \\
\text { groups? }\end{array}$ & No & Yes \\
\hline $\begin{array}{l}\text { What is the basis for the calculation of the amount } \\
\text { of social security contributions of farmers? }\end{array}$ & $\begin{array}{l}\text { per person/ } \\
\text { Number } \\
\text { of hectares }\end{array}$ & farm taxable profit \\
\hline $\begin{array}{l}\text { Is it possible for a farmer to have the following covered } \\
\text { by the social security system? (spouse, other people } \\
\text { working on the farm) }\end{array}$ & Yes & Yes \\
\hline Are all farmers subject to the same regulations? & No & No \\
\hline $\begin{array}{l}\text { How do farmers in your country pay health insurance } \\
\text { contributions? }\end{array}$ & $\begin{array}{l}\text { By state/or they } \\
\text { pay it them- } \\
\text { selves (farms } \\
\text { bigger than } 6 \\
\text { ha) }\end{array}$ & $\begin{array}{l}\text { Health insurance } \\
\text { contributions depend } \\
\text { on farm size. If the } \\
\text { farm is very small, } \\
\text { insurance contribution } \\
\text { is } 3 \% \text { min. monthly } \\
\text { salary (now min. } \\
\text { salary is } 400 \text { Euro), } \\
\text { other farms - 9\% min. } \\
\text { monthly salary. }\end{array}$ \\
\hline $\begin{array}{l}\text { Is the operation of a separate system for farmers linked } \\
\text { to a separate institution administering the 'agricultural } \\
\text { system'? }\end{array}$ & Yes & No \\
\hline $\begin{array}{l}\text { Which farmers are not covered by the agricultural } \\
\text { system? } \\
\text { - those with the smallest farms ('the poorest'), } \\
\text { - those with the largest farms ('the richest'), } \\
\text { - those conducting non-agricultural business activity }\end{array}$ & $\begin{array}{l}\text { Some people } \\
\text { conducting } \\
\text { non-agricultural } \\
\text { business activity }\end{array}$ & - \\
\hline $\begin{array}{l}\text { Is the social security system for farmers in your coun- } \\
\text { try self-financing? Please, indicate the (approximate) } \\
\text { participation of contributions in expenditure (in \%) }\end{array}$ & No & $\begin{array}{c}\text { Yes. } \\
\text { Social security } \\
\text { system - about } 5 \% \\
\text { of all contributions. }\end{array}$ \\
\hline
\end{tabular}




\begin{tabular}{|c|c|c|}
\hline Specification & Poland & Lithuania \\
\hline $\begin{array}{l}\text { If the system was not self-financing, } \\
\text { what was the amount of the State subsidy designated } \\
\text { for the system? (if the system did not require subsidies } \\
\text { from the State, please write } 0 \text { ) }\end{array}$ & $95 \%$ & 0 \\
\hline $\begin{array}{l}\text { Which of the following systems is in place: } \\
\text { - pay-as-you-go (current contributions are allocated } \\
\text { to the current benefits), } \\
\text { - fully funded (capital - current contributions are } \\
\text { collected in a separate account of the insured). }\end{array}$ & Pay-as-you-go & Pay-as-you-go \\
\hline When was the system created? & 1990 & 2000 \\
\hline
\end{tabular}

Source: own study.

Social insurance for farmers in Lithuania is based on common insurance, and farmers are treated like other social groups, which assures greater transparency of this insurance.

In Poland, the system of social insurance for farmers is perceived as socially unjust due to the fact that farmers, as a social and professional group, are regarded as entrepreneurs, who are subject to common social insurance yet they pay notably lower contributions (Pawłowska-Tyszko et al. 2015, p. 73). Therefore, social insurance for farmers in Poland was and still is a separate, privileged system. This solution results not only from a historical, but also an economic background, i.e., in contrast to Lithuania, the lack of taxation of farmers' income tax makes it impossible to make the contribution dependent on the amount of earned income (Felis 2015, pp. 38-47). It is probable that Lithuania, a smaller but equally agricultural country as Poland, ought to set a certain role model for the legislator with respect to introducing changes in the social insurance of farmers in Poland. Evidently, it is impossible to insure all people related to agriculture in the common insurance system, to conduct a full resolution of the institution handling insurance for farmers, and assure the immediate financial balance of the system.

\section{Conclusions}

The aforementioned systems' features can be advantageous and disadvantageous at the same time. For example, the low social contribution from farmers in Poland is - from the state budget point of view - the biggest disadvantage of the social insurance system for farmers; however, for the farmers themselves, it is an advantage. Conversely, in Lithuania, the lack of a special system for farmers is good for the state budget, but probably not for the farmers. So, thinking about directions for further changes, firstly, it is necessary to answer the question: why do we want to change it? The answers to this question are not simple and straightforward. There are separate insurance systems for farmers in many countries around the world; however, one should bear in mind the different financial and organizational rules which characterize them. At the same 
time, the introduction of the most radical changes which could improve their functioning, for example, in Poland, generally creates resistance and a conflict of interest for many different groups of people, like farmers and the rest of society. On the other hand, however, maintaining the current state of the system involves such economic factors like public resources, but it may also cause a sense of injustice. These systems also have to be adjusted to the current economic situation, so their comparison at the international level, especially in terms of their advantages and disadvantages at the same time, requires special care and prudence. Undoubtedly, however, the lack of any change is disturbing. While the discussion in Poland focuses on how (and if) contributions should depend on income, and if the system can be financially balanced to a greater extent, in Lithuania the level of the debate is at a higher, more advanced level, and concerns one aspect: how can we improve this element of the system?

\section{References}

Act 1990, Ustawa z dnia 20 grudnia 1990 r. o ubezpieczeniu społecznym rolników, [Act of 20 December 1990 on social insurance of farmers], Journal of Laws 216, item 277.

Agricultural Census, Farm Accounting Data Network An A to Z of methodology, ec.europa.eu/agriculture/rica/pdf/site_en.pdf (accessed: 10.04.2018).

Chybalski, F., Marcinkiewicz, E. (2016), The replacement rate: An imperfect indicator of pension adequacy in cross-country analyses, 'Social indicators research', Vol. 126, No. 1.

Cornelissen, R. (2008), Third-Country Nationals and the European Coordination of Social Security, 'European Journal of Social Security', Vol. 10, No. 4.

CSO (2015), Retirement and other pensions. Central Statistical Office. Warsaw.

CSO (2016), Retirement and other pensions. Central Statistical Office. Warsaw.

CSO (2017), Retirement and other pensions. Central Statistical Office. Warsaw.

European Network of Agricultural Social Protection Systems, http://www.enasp.eu/ about/ (accessed: 1.04.2018).

Eurostat (2012), Agriculture, fishery and forestry statistics Main results - 2010-11. Luxembourg.

Felis, P. (2015), Agricultural tax fiscal efficiency in Poland, 'Management Theory and Studies for Rural Business and Infrastructure Development', Vol. 37, No. 1.

Grakauskas, E., Marcijonas, A. (2005), Mokesčiai ir žemès ūkis Europos Sajungos ir Lietuvos teisinio reglamentavimo kontekstu, 'Teisè', No. 55.

Hagemejer, K. (2009), Rights-based approach to social security coverage expansion [in:] Holtzmann, R., Robalino, D.A., Takayama, Nm. (Ed.), Closing the coverage gap: The role of social pensions and other retirement income transfers, Washington, World Bank.

Hill, B., Blandford, D. (2007), Taxation Concessions As Instruments Of Agricultural Policy. The Agricultural Economics Society's $81^{\text {st }}$ Annual Conference, University of Reading. 
Jagła, W. (2011), Postulaty chłopskie z Rzeszowa 30 lat temu i dzisiaj (Peasant postulates from Rzeszów 30 years ago and today), 'Ubezpieczenia w rolnictwie. Materiały i studia', No. 40.

Juškevičienè, D. (2012), Žemès ūkio veiklą vykdančiu gyventojų tiesioginès mokesčių naštos diferencijavimo vertinimas. 'Management Theory and Studies for Rural Business and Infrastructure Development', No. 2 (31).

Juškevičienè, D., Lakis, A. (2010), Žemès ūkio valdu grupavimo mokesčių tikslais alternatyvos, 'Management Theory and Studies for Rural Business and Infrastructure Development', No. 22 (3).

Kotsioni, I., Chatzis, C., Chronopoulou, E., Linos, A. (2007), Social and occupational health protection for self-employed farmers in the European Union, 'Journal of Public Health', Vol. 15, Issue 4.

KRUS (2011), Quarterly Statistics of the Agricultural Social Insurance Fund. Kasa Rolniczego Ubezpieczenia Społecznego. Warszawa.

KRUS (2017), Quarterly Statistics of the Agricultural Social Insurance Fund. Kasa Rolniczego Ubezpieczenia Społecznego. Warszawa.

KRUS, www.krus.gov.pl (accessed: 25.01.2018).

Miceikiené, A., Besusparienè, E. (2016), The optimal tax system of the farmers formation, 'Management Theory and Studies for Rural Business and Infrastructure Development', No. 38 (3).

Miceikienè, A., Novošinskienė, A., Savickienė, J. (2014), Ūkininkų apmokestinimo naštos tyrimai, 'Ekonomika ir vadyba: aktualijos ir perspektyvos', No. 2 (34).

Musiał, D. (2014), Zróżnicowanie ubezpieczeń społecznych rolników w wybranych krajach Europy (The diversity of farmers' social insurance systems in chosen european countries), 'Roczniki Ekonomicze Kujawsko-Pomorskiej Szkoły Wyższej Bydgoszczy', No. 7.

Namiotko, V., Eirošius, S. (2014), The Analysis Of Social Insurance Systems For Farmers In Selected Eu Countries: Lessons Learned For Lithuania, 'Economy \& Business Journal', Vol. 8, No. 1.

NIK (2017), Analiza wykonania budżetu państwa i założeń polityki pieniężnej w 2016 roku (Analysis of the state budget implementation and monetary policy assumptions in 2016), Najwyższa Izba Kontroli, Warszawa.

Parlinska, A. (2008), Legal Aspects Of Polish Tax And Social Security In Agriculture, 'Aestimum', No. 53.

Pawłowska-Tyszko, J., et al. (2015), Current status and prospects of development of the tax system and insurance scheme of the Polish agriculture. Instytut Ekonomiki Rolnictwa i Gospodarki Żywnościowej - Państwowy Instytut Badawczy, Warszawa.

Savickienė, J., Slavickienė, A. (2008), Apmokestinimo bazès įtaka ūkio ekonominiam gyvybingumui. Apskaitos ir finansu mokslas ir studijos: problemos ir perspektyvos. Mokslo žurnalas. Akademija, Kauno.

Walczak, D. (2011), Uwarunkowania funkcjonowania systemu zabezpieczenia społecznego rolników w Polsce (Determinants of the functioning of the social security system for farmers in Poland), TNOiK, Torun. 
Walczak, D. (2017), Zmiany w uprzywilejowaniu emerytalnym rolników - reforma bez reformy (Changes in privileged pension scheme for farmers reform without reform), 'Ubezpieczenia w rolnictwie. Materiały i studia', No 1.

World Bank, https://data.worldbank.org/indicator/NV.AGR.TOTL.ZS (accessed: 10.04.2018).

Zhong, C., Turvey, C., Zhanga, J., Xu, C. (2011), Does taxation have real effects on agricultural output? Theory and empirical evidence from China, 'Journal of Economic Policy Reform', Vol. 14, No. 3.

\section{Streszczenie}

\section{Ubezpieczenie społeczne rolników w Polsce i na Litwie - analiza porównawcza}

Celem artykułu było przedstawienie ubezpieczenia społecznego rolników w Polsce i na Litwie. W pracy wykorzystano następujące metody badawcze: metoda opisowa, analiza literaturowa, analiza statystyczna oraz ekonomiczna analiza prawa. W wyniku przeprowadzonych badań stwierdzono, że w obu krajach występuje odmienny model ubezpieczeń społecznych dla rolników. Wynika to nie tylko z decyzji politycznych, ale zapewne i z innych uwarunkowań wpływających na rolnictwo w tych krajach. Podkreślenia wymaga fakt, że w Polsce ubezpieczenia te są dotowane w wysokości około $90 \%$, gdy tymczasem na Litwie system jest samowystarczalny.

Słowa kluczowe: ubezpieczenie społeczne, emerytura, rolnicy, przywileje 